\title{
ANI KSIĄŻĘ, ANI KUPIEC: SZACKI
}

Michał Luczewski

Uniwersytet Warszawski

Kiedy pracowałem nad jakimś artykułem, określiłem Jerzego Szackiego jako a towering figure of Polish sociology. Nie przypadło mu to do gustu. Po latach myślę, że w tej irytacji wyrażało się coś głębszego, może jakiś klucz do zrozumienia tego, kim był. Szacki nie chciał być towering, nie chciał nad niczym i nikim górować, nie chciał być najwybitniejszy. On na piedestał był stawiany przez nas, ale wcale nie czuł się na nim dobrze i jeśliby tylko mógł, czym prędzej zaszyłby się w swoim gabinecie na Lipowej. W pewien sposób w życiu Szackiego powtarzała się sytuacja z jego pierwszego pobytu w Paryżu. Otóż wielki Lucien Goldmann, który tak mocno wpłynął na myśl całej Warszawskiej Szkoły Historyków Idei, zaprosił młodego przybysza z Polski na uroczysta kolację. W drzwiach przywitała go służba domowa, w kuchni czekały wykwintne potrawy, a przy stole ustawiony był fotel dla głównego gościa. Goldmann był niecierpliwy, niezwykle wszystkim przejęty. Okazało się, że cały wieczór został przygotowany na cześć jego intelektualnego mistrza, Jeana Piageta. Ale Piaget nie przyszedł, chyba nawet nie odwołując swojej wizyty. Goldmannowi nie pozostało więc nic innego, jak usadzić Szackiego w fotelu Piageta i ofiarować mu wszystkie kulinarne wspaniałości, które zostały przygotowane dla towering figure ze Szwajcarii. Kiedy po półwieczu Szacki opowiadał mi tę anegdotę, śmiał się z niezręczności całej sytuacji. Samym tym śmiechem walczył z naszymi próbami usadowienia go w fotelu przeznaczonym dla współczesnego klasyka.

Usposobienie Szackiego - przyrodzoną niechęć do bycia obsadzanym w roli ,autorytetu” i „wybitnego myśliciela” - widać było bardzo dobrze w stylu jego pisania. W swoich książkach i artykułach nigdy nie próbował zwracać na siebie uwagi, nie ferował kontrowersyjnych sądów, nie tworzył nawet teorii, które - co wiemy od Roberta Mertona - mogłyby zapewnić mu socjologiczną nieśmiertelność. Szacki stał zawsze na uboczu, w cieniu, 
wolał dać miejsce innym: Durkheimowi, Simmelowi, Koselleckowi (którego spotkał dwa razy w życiu, ale wymienili tylko kilka zdawkowych uwag, bo Szacki dopiero potem się dowiedział, z kim rozmawiał), Znanieckiemu (którego spotkać nie było mu dane, choć mówił o nim tak, jakby się znali całe lata), Ossowskiemu (u którego się uczył), Kołakowskiemu (który był jego przyjacielem)... To oni - dzięki niemu - mieli grać główne role. To ich teorie, ich kontrowersyjne sądy, ich idee miały być na pierwszym planie. Stąd brały się tak charakterystyczne dla Szackiego wyliczenia: „po pierwsze”, „po drugie”, „po trzecie”..., „po siódme”. Nie rządziła nimi jakaś odgórna logika teorii (np.: makro-mezo-mikro albo poznanie-emocje-działania, albo pole-kapitał-habitus), lecz logika badanych idei. Swoja robotę traktował - tak mogło się zdawać - jako poślednią rola kronikarza, który opisuje dzieje idei. Może je trochę uporządkować, skonstruować kilka typologii, wskazać na genealogię, ale nie może ich zamknąć w jakichś prostych schematach. Tak tłumaczę typowe dla Szackiego zainteresowanie „paradoksami” (np. kontrrewolucyjnymi), „dylematami” (np. dylematami historiografii idei), „przeglądami” (np. przeglądem problematyki tradycji) i ,problemami” (np. problemami myśli socjologicznej) - i te jego nieustanne zastrzeżenia i zmiękczenia: „bodaj”, „być może”, ,jak się zdaje”, „mniejsza o”, ,z jednej strony, z drugiej strony”. Kryła się za tym wszystkim ironia. Bo Szacki był ironiczny, ale ironiczny na sposób dawnych romantyków. Prawdziwy pozytywista, syn oświecenia prędzej czy później musi dojść do postawy, która każe z pogodą akceptować ogrom i skomplikowanie świata i która wciąż powtarza: nibil novi sub sole. Nie jesteśmy w stanie w pełni niczego opisać i wyjaśnić, a wszystko już było. Ideologiczne i naukowe walki, które toczymy, były dla Szackiego jedynie kolejną odsłoną walk przeszłości; wszelkie rewolucyjne idee - kolejnym wcieleniem idei dawnych. Kiedy starałem się przedstawić mu jakiś kolejny, ,przełomowy” pomysł, czułem, że za każdym razem mógłby powtórzyć to, co Pitirim Sorokin mówił do Charlesa Tilly’ego: „Bardzo dobrze, panie Tilly, ale Platon powiedział to lepiej”. Pierwszy numer „Stanu Rzeczy” chcieliśmy poświęcić kwestii kryzysu nauk społecznych. On stanowczo nam to odradził, bo przecież socjologia znajduje się w kryzysie od swojego początku i ile można o tym pisać. Zrobiliśmy więc numer o demonach.

Szacki lekceważąco podchodził do swoich wykładów i legendarnych seminariów: „Ja nie jestem fanatyk zajęć dydaktycznych”. Lekceważąco podchodził też do swoich książek. O monumentalnej Historii myśli socjologicznej mówił, że „człowieka 1/10 naprawdę interesuje (Cooley, Szkoci), 2/10 - interesuje średnio, a przynajmniej połowa nie interesuje w ogóle, ale 
musi być”. Profesor nie lubił wreszcie sytuacji oficjalnych: „Z moim zdrowiem wszystko w porządku - pisał, kiedy zanadto się o niego troskałem - jeśli nie liczyć nabytego braku odporności na zjazdy i kongresy". Kiedy poprosiliśmy go, żeby został patronem naszego instytutowego seminarium socjologicznego, on z uśmiechem odparł: „O, patronem to ja mogę być zawsze!’. Podobnie zareagował na prośbę o bycie szefem Rady Naukowej „Stanu Rzeczy”: „Miło mi i zgadzam się, oczywiście, jeżeli pismo musi mieć prócz redakcji i artykułów Radę Naukową". Szacki nigdy nie aspirował do roli mistrza i klasyka. Być może było to związane z tym, że - jak mi opowiadał - Jarosławowi Markowi Rymkiewiczowi mama w dzieciństwie czytała Anhellego, on zaś musiał się zadowolić Koziotkiem Matotkiem.

Podchodził do siebie z dużym dystansem. Kiedy wygłosił prestiżowe wykłady kopernikańskie w Toruniu, „bał się do nich zajrzeć”. Podczas odnowienia jego doktoratu nie usłyszeliśmy opowieści o grantach, stypendiach, wojażach zagranicznych i zespołach badawczych, które konstytuuja dziś nasz naukowy status, ale o tym, jak wszystko wokół się zmienia, jeśli wystarczająco długo nie ruszamy się z miejsca. Gdy otrzymywał nagrodę polskiego PEN Clubu, wyraził zdziwienie, że wyróżniono go w kategorii eseju, choć zgodził się po namyśle, że rzeczywiście do wszystkiego, co pisze, dobrze pasuje kategoria eseju: eseju, czyli próby. Swoje klasyczne prace określał jako książeczki („książeczka o utopii”, „książeczka o tradycji” etc.), Historie myśli socjologičnej napisał zaś nie dlatego, że chciał ją napisać, ona - jak tłumaczył - po prostu sama się napisała przy okazji prowadzonych przez lata wykładów. Ale nawet gdy tysiąc stron pisze się samo, można się zmęczyć. Trudno się zresztą dziwić, skoro całość teorii Luhmanna „wydaje się odpychająca”, język Bourdieu jest „eliptyczny i ciemny”, a precyzja wywodów Habermasa - „często pozorna”. Przeczytajcie jeszcze raz Historie myśli socjologicænej, a dużo dowiecie się o samym profesorze. Tradycje i Spotkania z utopia pisał z kolei z prawdziwa pasją. Widać to np. w takich fragmentach, które musiały sprawiać mu dużo radości: „Niewielu z nas gustowałoby zapewne w życiu płciowym zorganizowanym na wzór Państwa Stońca T. Campanelli [...]. Niezbyt pociągająca wydaje mi się również wizja Dom Deschampsa". Kto ciekaw, co Szackiego nie pociagało i w jakim życiu seksualnym nie gustował, niech zajrzy czym prędzej na strony 169 i 170 Spotkań...

Profesor podkreślał, że nie miał żadnego systemu pracy, że od czasu studiów był niezbyt pilny i może tylko podziwiać mniej niż on leniwych historyków, którzy wyposażeni w doskonałe systemy fiszek mogli pisać wielkie książki. Ponieważ nigdy nie opuszczała go niepewność, Szacki do 
każdego występu publicznego solidnie się przygotowywał. Dotąd widzę zapełnione ołówkiem karteczki, z których korzystał, gdy zaprosiliśmy go na debatę pod tytułem, który nie mógł mu się spodobać: „Patriotyzm. Król versus Szacki”. Choć o patriotyzmie wiedział wszystko, choć zajmował się nim naukowo niemal pięćdziesiąt lat, to i tak uznał za stosowne, żeby przygotować się do jakiegoś nieważnego wystąpienia, na które zaprosili go jacyś nieważni studenci. A może te wystąpienia i ci studenci byli dla niego ważniejsi, niż myśleliśmy? Przy okazji zrozumiałem wtedy, że patriotyzm był dla niego nie tylko wzniosłą idea. Pamiętam, jak trochę się krzywił, kiedy Marcin Król podkreślał, że Szacki mimo wielu ofert uniwersytetów z Zachodu nigdy nie zdecydował się na dłużej opuścić własnego Uniwersytetu.

Współpraca z Szackim przez kilkanaście lat była dla mnie wielkim darem. Dziwiłem się, że na Lipowej obok mnie nie ustawia się kolejka młodych, że nie ma tutaj pielgrzymek z całej Polski. Miałem wrażenie, że gabinet Szackiego był sanctum sanctorum polskiej socjologii. Kiedy profesor do niego wchodził, przypominał mi Machiavellego, który w słynnym liście do Vettoriego pisał: „Kiedy zapada wieczór, wracam do domu, wchodzę do swojej biblioteki i już na jej progu zrzucam z siebie codzienną, zbrukaną błotem odzież, a przywdziewam szaty godne królewskiego dworu; tak dostojnie ubrany wkraczam w odwieczną dziedzinę ludzi starożytnych, gdzie uprzejmie przez nich przyjęty posilam się tym pokarmem, który, tylko on, jest moim i do którego spożywania urodziłem się”. Jedyna różnica polegała na tym, że Szacki nie zakładał „szat godnych królewskiego dworu”, ale kapcie i wytarte spodnie. Nie dbał o strój. Komuś, kto przeżył wojnę i biedę komunizmu, kto kilka lat po ślubie był w zasadzie bezdomny, wystarczało niewiele. Kiedy wracał do zniszczonej Warszawy, majątku mial - jak wspominał - ,jedna puszkę po konserwach, jedną łyżkę, jedną zapasową koszulę, sznurkową torbę".

Nina Kraśko w swoim wspomnieniu powiedziała, że gabinet Szackiego miał sześć metrów kwadratowych. To nieprawda. Miał znacznie mniej i każdego roku coraz bardziej się kurczył. Systematycznie, dzień za dniem zapełniały go bowiem kolejne kolumny książek. Profesor nie miał względu na rodzinny budżet. Gdy tylko pojawiła się jakakolwiek nowa pozycja z tematu, który go zajmował (ostatnio był to przede wszystkim nacjonalizm), natychmiast zamawial ja przez Amazon, a następnie znajdował dla niej miejsce na którymś z rosnących stosów. Z czasem taka książka wypełniała się delikatnymi podkreśleniami ołówkiem i karteczkami. Gdy Szacki miał poczucie, że dany temat już wyczerpał, a było to mniej więcej raz na dekadę, 
ofiarowywał wszystkie swoje książki naszej bibliotece. Wtedy przyjeżdżał dyrektor Janusz Siek i zawoził obfity zbiór na Krakowskie Przedmieście. Przypominało to potlacz. Kolejnym pokoleniom filozofów i socjologów, które nawet o tym nie wiedziały, Szacki jednym gestem oddawał to, co miał najcenniejszego. A jego gabinet - tylko na chwilę - powracał do swoich standardowych rozmiarów.

Odkąd we wczesnym liceum przeczytałem jego książkę Spotkania z utopia, sam Szacki był dla mnie utopią. (Rozszerzając jego typologię, moglibyśmy określić taką utopię jako utopię personalna). Wiedziałem, że profesor jest towering figure, ale nie wiedziałem nawet, czy gdzieś istnieje. Wydawało mi się, że musi zamieszkiwać jakieś idealne przestrzenie polskiej humanistyki razem z Leszkiem Kołakowskim i Bronisławem Baczka. Wtedy nie przyszło mi nawet do głowy, że mogły ich łączyć nie tylko zainteresowania, ale przede wszystkim wspólna droga, z której ich zainteresowania wynikały. Pisali o spotkaniach z utopią, bo sami najpierw stali się jej częścią.

Kiedy w 1998 roku pojawiłem się w Warszawie, Szacki raptem się zmaterializował. Oto najzwyczajniej w świecie prowadził zajęcia w Instytucie Socjologii UW, utopia zstąpiła na ziemię. Krążyły wśród nas legendy o jego małomówności. Ponoć Szacki miał do wykorzystania jedynie trzysta słów dziennie, więc mówił jeszcze trochę w godzinach przedpołudniowych, ale im bliżej wieczora, tym bardziej swoje słowa musiał ważyć. Od 16:00 wypowiadał się już jedynie półsłówkami, a o godzinie 21:00 zapadał w absolutne milczenie. Jeden $\mathrm{z}$ wykładowców opowiadał mi, jak z powodu tej przypadłości Szackiego cierpieli dziennikarze. - Panie Profesorze, czy znalazłby Pan czas, żeby porozmawiać o [tu wstawić bardzo ważne wydarzenie czy zjawisko, które ostatnio zelektryzowało opinię publiczna] - Nie. - A może moglibyśmy się spotkać? - Nie. - Zwięzłe odpowiedzi Szackiego wprawiały dziennikarzy w popłoch. Inaczej niż w przypadku pozostałych socjologów, którzy czują przymus mnożenia prawdziwych i fikcyjnych powodów, kiedy odmawiają wywiadu, Szacki z niczego się nie tłumaczył. Nie chciał mówić - nie mówił. To milczenie Szackiego sprawiało, że wszyscy czuliśmy się przy nim onieśmieleni. Zaczynało się jeszcze od egzaminu, który miał charakter inicjacji. Zgodnie ze świadectwami starszych roczników, przekazywanych z pokolenia na pokolenie, profesor zadawał pytanie, po czym znikał za kłębami tytoniowego dymu, czekając, aż delikwent skończy. Z jego kamiennej twarzy nigdy nie można było odczytać, czy odpowiedź była zadowalająca, czy też nie. Kolejne pytanie, milczenie profesora. Kolejne pytanie, kłęby dymu, milczenie. Indeks, ocena. Następny, proszę. Po takim rytuale Szacki nabierał niemal boskiego statusu. Nie 
dziwiłem się, że wywierał takie wrażenie na nas; zaskoczyło mnie jednak to, że taki sam nabożny, pełen czci stosunek do niego mieli ludzie, którzy byli naszymi nauczycielami. Podczas laudacji ku czci Szackiego, którą wygłosił kiedyś Paweł Śpiewak, zobaczyłem ten sam niepewny wzrok, to samo ukradkowe spoglądanie na mistrza, które od samego początku były naszym udziałem.

Legendy dotyczące Szackiego przeraziły mnie i sprawiły, że nie zdecydowałem się podjąć wyzwania i nie podszedłem do egzaminu u niego. Ale wszystkie socjologiczne drogi znów prowadziły do Szackiego. Pisałem o utopii - jego ksiażki były pierwsze na liście, o konserwatyzmie - musiałem sięgnać po Kontrrewolucyjne paradoksy i Tradycje, o ideologii - pomoca był encyklopedyczny artykuł z Dylematów..., o ideologii narodowej - trzeba było przeczytać Ojczyzne, naród, rewolucję. Kiedy zająłem się nacjonalizmem gospodarczym, po Romana Rybarskiego znów sięgnąłem dzięki Szackiemu. Gdziekolwiek próbowałem się ruszyć, tam zawsze pojawiał się Szacki.

$\mathrm{Na}$ seminarium Marcina Króla omawialiśmy klasyczną typologię z Tradycji, a na zajęciach śp. Tomasza Merty i Dariusza Gawina czytaliśmy Liberalizm po komunizmie i Kontrrewolucyjne paradoksy. Ta ostatnia książka była wtedy nie do zdobycia, musieliśmy czytać jej niemiłosiernie zniszczone egzemplarze w czytelni WFiS. Pamiętam kolejne strony, w których każde zdanie było podkreślone a to długopisem, a to ołówkiem, a to różowa kredką. Trudno się zresztą dziwić warszawskim studentom, że podkreślali wszystko. Kontrrewolucyjne paradoksy to książka - jak gdzieś zauważył Szczepan Twardoch - w której nie ma zbędnego zdania. Żeby jednak zwiększyć mój czytelniczy komfort i nie dokładać kolejnych podkreśleń do nałożonych przez dekady i pokolenia warstw, rozpocząłem polowanie na białego kruka. Kiedy jeden jedyny raz razu wreszcie ktoś wystawił Kontrrewolucyjne paradoksy na sprzedaż, stoczyłem o nią zacięty i przegrany niestety bój z Wojtkiem Przybylskim. Ale to on zrujnował swój studencki budżet.

W kolejnych latach coraz trudniej było mi znaleźć temat, którego Szacki nie podjął. Zajmowałem się połączeniem obiektywizmu i subiektywizmu (a także kultury i polityki) - Szacki; związkami filozofii z socjologia (a także socjologii z historia) - Szacki; rolą klasyków i tradycji - Szacki; teorią narodu - Szacki; teorią nowoczesności - Szacki. Szacki, Szacki, Szacki. Był wszędzie. Miał za sobą doświadczenie badań terenowych ze Stanisławem Ossowskim w Galicji. Bardzo dobrze znał twórczość Franciszka Bujaka i monografię Żmiącej (był autorem biogramu Bujaka i wyboru fragmentów jego pism w Stu latach socjologï polskiej). Nieobce mu były nawet - jak się wydaje - kwestie demonologiczne, o których pisał w swoim artykule 
z 1958 roku pt. W walce z. urojonym Antychrystem. Bardzo żałuję, że nie usłyszałem jego bardziej rozbudowanych refleksji o demonach, gdyż kłopoty ze zdrowiem nie pozwoliły mu wziąć udziału w promocji pierwszego numeru „Stanu Rzeczy” w Pałacu Staszica, na którą - dla niego - przyszły tłumy.

Ponieważ uciekając od Szackiego, cały czas i tak do niego wracałem, postanowiłem zalegalizować ten platoniczny związek i zwrócić się do niego z prośbą, żeby został moim opiekunem naukowym. Choć na przełomie XX i XXI wieku Instytut Socjologii oferował studentom niezliczoną ilość seminariów, warsztatów i konwersatoriów (te czasy już nigdy nie wróca), jakoś nie mogłem się na studiach odnaleźć. Szukałem więc przewodnika, który mógłby mi wskazać kierunek, ale przewodnicy albo nie mieli czasu, albo nie byli przewodnikami. I wtedy napisałem najdłuższy list w życiu, przedstawiłem się, kim jestem, co chcę robić i o czym chciałbym pisać. W wielkim napięciu oczekiwałem na odpowiedź, która - ku mojemu zaskoczeniu - nadeszła bardzo szybko (profesor zawsze na listy odpowiadał niemal od razu). Mail od Szackiego gdzieś mi zginął w odmętach utraconych kont internetowych, ale do dzisiaj pamiętam cała jego treść: „Możemy spróbować - JS".

To był cały Szacki. Za zwięzłością i pozornym chłodem kryła się wspaniałomyślność. Jednym zdawkowym mailem nieznanemu sobie socjologowi na niemal dwie kolejne dekady ofiarował swój czas, mądrość i uwagę. Mój desperacki krok mogło tłumaczyć tylko to, że wydawało mi się, że jedynie Szacki może mi pomóc. I pomógł. Pomagał jak nikt inny przez kolejne lata - swoimi pomysłami, pożyczanymi i darowanymi książkami, rozmowami, niezliczonymi rekomendacjami („Jak trzeba, to napiszę. Czekam na sygnał. JS”), radami (np. „stopnie naukowe trzeba robić jak najszybciej, a nad książkami można potem sobie jeszcze pracować”).

Przez te wszystkie lata zadręczałem Szackiego artykułami, książkami i książeczkami, które zawsze recenzował, zwykle podkreślając, że kiedyś już coś podobnego czytał (albo że ja już coś podobnego napisałem). Moja wdzięczność wobec profesora rosła wraz z upływem czasu, gdyż był on jak sam siebie określał - „człowiekiem środka”, ja zaś miałem skłonność do radykalizmu. Różniło nas dużo, ale przez to to, co nas łączyło: nauka, stawała się jeszcze ważniejsza. Uderzająca cechą Szackiego była ciekawość idei i szacunek wobec tych, którzy mogli się z nim nie zgadzać w ocenie rzeczywistości społecznej. Choć Szacki dużo czasu spędził na pobożnych lekturach, podobnie jak Weber nie miał słuchu religijnego. Jego stosunek do metafizyki dobrze wyrażała pewna scenka z któregoś z Tygodni Kultury Chrześcijańskiej. To był chyba jego jedyny wykład w kościele. Szacki 
wspominał, że miał mówić z ambony. Kłopot polegał na tym, że musiał przejść koło Najświętszego Sakramentu, odwrócił się więc w jego kierunku i chciał wykonać jakiś gest, ale nie mógł się zdecydować - jaki. Wtedy proboszcz zwolnił go z tych dylematów i kazał mu po prostu iść dalej. Szacki wyprostował się i rozprężył. W jego początkowym wahaniu przejawiało się to, że chciał okazać szacunek swojemu gospodarzowi, a gospodarz - okazał szacunek Szackiemu. I tak tworzyła się kultura tych dziwnych lat 80.

Czytając z Mertą i Gawinem Liberaližm po komuniz̨mie, zwracaliśmy uwage na to, że Szacki w pierwszej Solidarności (mimo że sam do niej należał i dał się ponieść wzmożeniu patriotycznemu i moralnemu, czego się później trochę wstydził) nie widział zapowiedzi polskiej wolności, ale raczej jej zagrożenie. Bardzo jednak spodobała mu się książeczka (!) o Solidarności, którą razem z moimi studentami napisaliśmy w zupełnie innym niż on duchu: „Książeczka o Solidarności znakomita pod względem formalnym i dla mnie wzruszająca nie tylko jako okazja do wspomnień, ale i jako świadectwo, że są jeszcze tacy ludzie, którym Solidarność kojarzy się z czasem przyszłym (chociaż sam do nich nie należę i nie należałem). Pewno to niezbyt zrozumiałe, ale za wiele musiałbym pisać, aby to wytłumaczyć". Spotkania z Szackim były dla mnie doświadczeniem naukowej utopii, doświadczeniem sfery publicznej, gdzie razem - niezależnie od wszystkich hierarchii i poglądów politycznych - możemy się spotkać.

Ostatni list, na który mi odpisał, dotyczył książki, nad którą się strasznie męczyłem - i dalej się męczę: „Szanowny Panie Profesorze, napisałem habilitację, ale jest ona może na granicy teoretycznego szaleństwa, bo Pana Żonę głowa rozbolała od nazwisk i prób syntezy Ricœura, Taylora, Szackiego etc. Panią Profesor prosiłem o formalna recenzję, ale wiem, że ma Pan jeszcze dużo innych spraw na głowie, więc przesyłam, żeby po prostu Pan wiedział, że nie dałem się robocie administracyjnej i zarządczej, tudzież politycznej, ale że pozostaję wierny mojemu pierwszemu powołaniu. Jeśli znalazłby Pan czas, żeby choćby zerknać na książkę - i wydać wyrok skazujący bądź ułaskawiający, byłbym - jak zwykle - bardzo wdzięczny. Tymczasem pozdrawiam bardzo serdecznie i życzę dużo zdrowia, ML”.

Szacki jak zwykle odpowiedział błyskawicznie: „Drogi Panie Michale: Jestem, oczywiście, bardzo ciekaw Pana książki, z pewnością na nią «zerknę», ale jestem w dość kiepskiej formie i zajmie mi to pewnie sporo czasu. Pozdrawiam JS". Tym razem zabrało to jednak więcej czasu, niż się i on, i ja spodziewaliśmy. 
Wspaniałomyślność Szackiego sprawiała, że zacząłem pisać do niego co pewien czas coś w rodzaju listów miłosnych. Nie wiem, jak na nie reagował. Cóż, nie były one w jego stylu: „Szanowny Panie Profesorze! Wszystkiego dobrego w dniu urodzin. Proszę utrzymać «cykle Szackiego» (jedna klasyczna książka na 10 lat) - tak, żeby przejść jeszcze minimum pięć cykli, przy czym każda Pana książka powoduje powstanie kolejnych cykli u uczniów, którym też udaje się napisać czasem coś dobrego, których to książki powoduja kolejne cykle u innych - no i tak tworzy się polska socjologia. Tylko nie wiem, jak ta socjologia będzie w przyszłości wyglądać, bo zamiast pisać wielkie dzieła, będziemy zbierać wiele punktów. Gram w coś takiego z moimi dziećmi - daję im punkty za to, że sa grzeczne, i odejmuję, kiedy są niegrzeczne. Bardzo dobrze działa, bo wkrótce już zapominają, po co te punkty zbieraja, ale je zbierają i wciąż chcą mieć więcej. Ale już nie narzekam i kończę: Niech jak najdłużej - z Panem - żyje stara, dobra polska humanistyka. Z wdzięcznością za tyle lat współpracy, Michał”.

Kiedy był w szpitalu, napisałem do niego chyba najkrótszy list - list, który pod względem formy, ale nie treści był bardzo w jego duchu. Temat: „Dzień nauczyciela”. „Szanowny Panie Profesorze, jest jw., a ja pomyślałem, że nie mam do kogo napisać poza Panem. Ponieważ jest Pan moim jedynym nauczycielem, proszę przyjąć te staroświeckie życzenia. Życzę przede wszystkim zdrowia, mam nadzieję, że będzie mógł Pan wrócić szybko do domu. Michał". Ten nieznośny czasem patos przełamywałem przesyłanymi mu nonsensownymi ciekawostkami, które - jak mi się wydawało - bardzo lubił. Odkryłem na przykład, że w klasycznej monografii Murzynowo autorstwa Jacka Olędzkiego, wydanej w 1991 roku, Szacki został określony jako... młody socjolog, a miał wtedy 62 lata! Gdy mu o tym powiedziałem, roześmiał się i powiedział: „Tak już to jest, najpierw jako socjologowie jesteśmy cały czas młodzi, a potem już od razu starzy". To wyraźnie spóźnione określenie brało się z nieprzewidywalnego procesu wydawniczego lat 80. Badania Olędzkiego trwały już od 1978 roku, a w wyniku zawirowań stanu wojennego ich wyniki długo nie mogły się ukazać, zwłaszcza że traktowały o wsi, blisko której urodził się Lech Wałęsa, i o tym, że największe rozrabiaki z regionu sikały do chrzcielnicy.

Szczodrość Szackiego brała się - jak sądzę - z jego poczucia długu wobec poprzednich pokoleń, z poczucia, że sam jest częścią socjologicznej tradycji. Socjologia nie była dla profesora abstrakcyjnym dziedzictwem, to była tradycja przeżywana. Przeżywana na uniwersyteckich seminariach i podczas badań terenowych, ale przede wszystkim poprzez kontakt z nauczycielami. Uderzało mnie, jak pięknie o nich mówił. Jego pierwsza pro- 
motorka, u której napisał pracę magisterską o Mochnackim, Nina Assorodobraj była - jak wspominał - „osobą niesłychanej solidności, rzetelności, ale zarazem z tą masą powściągów, z naturalną nieśmiałością, która się trochę bała powiedzieć zdecydowanie cokolwiek na dany temat, dopóki wszystkiego nie przeczytała i nie przemyślała. Nie chcę powiedzieć, że Ossowski mówił lekko i byle co, tylko [reprezentował] inny sposób myślenia i niewatpliwie miał lepszą szkołę filozoficzną za sobą i chyba wyraźniejsze poglądy własne. [...] Pani profesor uważała - mówił o niej - że ja mam wprawdzie pewne zdolności, ale mam też poważne skazy charakteru polegające w szczególności na braku samodyscypliny i niedostatecznej pracowitości, w związku z czym wpadła na myśl, żeby oddać mnie w ręce Bronisława Baczki, który był twardszy od niej i który powinien był dać sobie ze mna radę".

O Baczce Szacki mówił z niezwykłym szacunkiem, odnosił się do niego jak do swojego mistrza, co mnie bardzo dziwiło, gdyż dzieliło ich ledwie kilka lat. Wedle jego słów, Baczko był człowiekiem, który łączył w sobie dwie cechy: „Niezwykłą ludzką dobroć, troskę o to, jakie kłopoty może mieć ten drugi człowiek. To się odczuwało przy najrozmaitszych okazjach, materialnych, zdrowotnych. [...] Gdyby mnie ktoś zapytał, czy spotkałem w życiu kogoś, kto pasuje do wyobrażenia chrześcijańskiego świętego, to on przede wszystkim przyszedłby mi do głowy. [...] A z drugiej strony, był to człowiek niewiarygodnej wręcz pracowitości, z taką żelazną dyscyplina, mając rozmaite obowiązki typu: a to odprowadzić dziecko do szkoły, a to posprzątać, a to jeszcze coś innego, no ileś tam godzin dziennie, koniecznie, [spędzał] nad księgami. Owszem, wypoczynek letni, ale przy okazji przeczytać dwa tomy o ruchu fenomenologicznym, które się właśnie w Holandii ukazały. [...] On w czasie naszej znajomości się bardzo zmienił. W każdym razie początkowo wyglądało na to, że jemu brakuje nieco poczucia humoru, takiego zmysłu nonsensu, pewnych takich cech, które nam, tym młodszym, wydawały się całkiem zwyczajne. Był taki trochę do przesady serio, choć jednocześnie on miał jakąś zarazem świadomość, że poczucie humoru to trzeba mieć. I on się go nauczył. On się naprawdę go nauczył".

Szacki miał świadomość, jak wiele zawdzięczał swoim nauczycielom. Nina Assorodobraj była uczennicą Czarnowskiego, a Czarnowski uczniem uczniów Durkheima: Huberta i Maussa. Czy może zatem dziwić to, że Szacki poświęcił Durkheimowi monografię (kolejna „,książeczkę”), która po raz pierwszy w sposób całościowy w języku polskim przedstawiła myśl francuskiego klasyka? I czy może dziwić, że taką samą książeczkę po- 
święcił Znanieckiemu, od którego poprzez Stanisława Ossowskiego i Jana Strzeleckiego biegła nić polskiej socjologii humanistycznej, której Szacki był spadkobierca?

Przed Szackim miałem zawsze poczucie respektu, które czasami przeradzało się w bojaźń i drżenie. Kiedy nadarzyła się wyjątkowa okazja wygłosić z nim wykład o narodzie i nacjonalizmie - a taka okazja nadarzyła się tylko raz na sto lat polskiej socjologii, ba, raz w całej historii myśli socjologicznej - przygotowywałem się do tego tygodniami. Ale gdy ten wypatrywany dzień wreszcie nadszedł, po raz pierwszy w życiu straciłem głos. Nie mogłem wydobyć z siebie ani słowa. Całą rzecz musieliśmy ze smutkiem odwołać. Może był to skutek zapalenia krtani, może stresu, a może zapalenia krtani spowodowanego stresem? Z powodu tego typu doświadczeń miałem więc wielką satysfakcję, gdy to Szackiego wprawiłem w bojaźń i drżenie i gdy to on przeze mnie prawie zaniemówił. Otóż poprosiłem go o wywiad biograficzny. Pierwszy raz widziałem go w sytuacji zagubienia: „Ja przypuszczałem zresztą - poskarżył się - że pan będzie jakieś pytania zadawał, a nie że będzie to taki monolog, bo w monologach to ja jestem raczej kiepski’" Ten wywiad, którego nie dokończyłem, a początek gdzieś, niestety!, zgubiłem, pozwala mi robić to, co robił Szacki, kiedy chciał kogoś zrozumieć: ująć myśliciela jego własnymi słowami. Przytoczę więc dwa fragmenty, które pokażą, że poczucie humoru Szacki nabył bardzo wcześnie i że mógł być w tym zakresie nauczycielem Bronisława Baczki. Tam, we własnych doświadczeniach z młodości tkwiło - jak myślę - najgłębsze źródło jego socjologii, jego wyczucie paradoksów i dylematów.

„Wyobrażałem sobie to wszystko nieco inaczej. To znaczy: wyobrażałem sobie raczej studia politechniczne, z tego powodu poszedłem do liceum matematyczno-fizycznego, gdzie nie miałem łaciny, której potem musiałem się uczyć, by mnie przyjęli, bo warunkowo przyjęto mnie na uniwersytet do czasu uzupełnienia łaciny. No więc się jej uczyłem, aż do momentu, gdy się okazało, że jej się uczyłem niepotrzebnie, albowiem ten wymóg został zniesiony".

„W miarę starań o podwyższenie tętna życia ideowego czy politycznego zaczęły się coraz większe starania kierownictwa [PZPR] o to, żeby zrobić z nas nie tylko uczonych marksistów, ale i działaczy. No więc się zaczęły takie rozmaite misje terenowe. Dajmy na to zmiana cen: - Jedźcie tłumaczyć ludziom, dlaczego to jest niezbędne. Stalin umarł - jedźcie w teren ludzi pocieszać. [...] No i tak pocieszaliśmy z dobrym skutkiem zresztą, tam nie było żadnych zbiorowych samobójstw, aktów histerii. Ludzie przeżyli. Jak prymasa Wyszyńskiego zamknięto, to też nas wysłano, by lu- 
dziom tłumaczyć. Miałem szczęście. Ja wtedy jechałem ze straszną obawą, co ci włościanie powiedzą na to, że prymasa zamknięto. Jest to zebranie gromadzkie. Ja, tak możliwie najbardziej delikatnie jak umiem [tłumaczę], że tak, że tak, że to internowanie tylko, a nie uwięzienie, i tu wrzask się rozlega: - Trzeba było go porządnie zamknać! To choroba, przycisnąć go! To dranie! Nie wiedziałem, co się dzieje. To szczęście polegało na tym, że ja trafiłem do jednej z tych niewielu mariawickich wsi, które na Mazowszu były. Więc to były tego rodzaju historie”.

Szacki postrzegał myśl socjologiczną jako niekończące mierzenie się z „problemami i dylematami”. Socjologia rozpoczynała się dla niego tam, gdzie tracimy pewność i odkrywamy paradoksy. Wspomnienie o nim powinno więc kończyć się paradoksem: Szacki robił wszystko, żeby nie być klasykiem, ale i tak się nim stał. Wskazuje to na dziwny status socjologii, który zbliża ją do literatury pięknej. Wielkość zdobywamy tu, stając się częścią tradycji, powracając do mistrzów, opisując wielkość innych, nie - własna. Raczej niż oryginalności poszukujemy dawnych pytań i ksiag. Choć sami nie jesteśmy piękni, płynie przez nas czasem prąd piękności.

Nie wiem, czy Szacki tak to widział. Jeśli nawet, to z pewnością nie użyłby takich słów. Tym bardziej nie użyłby porównania, które mi się nieodparcie, kiedy o nim myślę, nasuwa. Kiedyś wysłałem mu link do broszurki Eugeniusza Jarry: Kardynat Wyszyński: Prymas-socjolog. Bardzo spodobał mi się ten tytuł, ale myślę, że bardziej niż do Wyszyńskiego pasowałby do Szackiego. Szacki był dla mnie właśnie prymasem-socjologiem, który nastapił wtedy, gdy wielcy królowie socjologii umarli. Gdy tron klasyków pozostał pusty, on zajął ich miejsce. W tym trudnym dla nauki czasie, gdy dawnych klasyków już nie ma, a nowi jeszcze nie nadeszli, Szackiemu przypadła godność interrexa, która zgodnie z polską tradycja piastowali właśnie prymasowie. To dzięki niemu odbudowywaliśmy ciagłość myśli socjologicznej. On chciał prowadzić nas do mistrzów, ale nie chciał ich przesłaniać. To oni mieli górować nad nami, oni mieli być towering figures, nie on. Dlatego stawał w pół drogi i pozwalał nam iść dalej. Szacki będzie dla nas ważny tak długo, jak długo będziemy zadawać podstawowe pytania o świat, w którym żyjemy. Takie rozumienie humanistyki wydaje mi się jednak coraz bardziej zagrożone. Zagrożone więc będzie znaczenie książek Szackiego, które w świecie owładniętym przymusem oryginalności lub wpisywania się w szkoły będa coraz mniej zrozumiałe. Sam Szacki jeszcze w latach 80. przewidywał upadek socjologii. W wywiadzie przeprowadzonym przez Wiktora Osiatyńskiego mówił: „Ja w ogóle nie jestem pewien, czy socjologia utrzyma się jako dyscyplina, ponieważ w pewnym sensie jest 
to nauka bez przedmiotu. To jest nauka o rozmaitych «resztkach», które się nigdzie indziej nie mieściły, a które stopniowo są dalej dzielone między siebie przez inne dyscypliny. [...] Oczywiście ten obiekt refleksji, jakim jest społeczeństwo, na pewno nie zniknie, a tym samym pozostanie potrzeba jakiejś «nauki o społeczeństwie». Mam natomiast bardzo poważne wątpliwości co do tego, czy nauką tą będzie socjologia, jaką dzisiaj znamy”. Jeśli nawet socjologia zatraci się w coraz większej specjalizacji i podnoszeniu efektywności, jeśli stanie się dosłownie grą resztkami, to Szacki nadal będzie czytany. Już nie przez socjologów, ale przez tych, którzy w drodze do rozumienia współczesnego świata spotkają się z interrexem. Ten wyprowadzi ich poza podziały ludzkiej wiedzy do dawnych mistrzów, którzy takich podziałów nie znali. Szacki nie potrzebował bronienia granic dyscyplin akademickich, potrzebował myślenia o człowieku, które nie zna granic. 